\title{
France to renovate natural history museum
}

Paris

The French science ministry has vowed to end decades of neglect of the Natural History Museum in Paris, and intends later this month to announce a ten-year, FF2.6 billion (US \$420 million) renovation as part of its budget for 2000 .

The government also stepped in last week to address the museum's much criticitized overall strategy and administration. Instead of appointing a successor to palaeontologist Henry de Lumley, who has just ended his term of office as director, it appointed an emergency interim administrator, JeanClaude Moreno, charged with preparing a major reform of the museum.

For the research aspects, Moreno - who admits to having little knowledge of sciencewill be aided by a "committee of scientific orientation" of top museum scientists, including foreign ones. "We need to learn from the experience of those elsewhere," says Moreno.

The Paris museum's architecture and research collections are in decay, it suffers from bureaucracy, and it lacks a strategy to balance its core missions: research, informing the public, and the curation of its collections.

De Lumley has been credited with making substantial improvements. But decades of financial neglect have left the museum in need of an ambitious rescue programme.

The top priority is renovation and safety, says Vincent Courtillot, director of research at the science ministry. Reports by independent government panels have warned that much of the museum fails to meet safety requirements - staff are at risk from fire, electrocution, dangerous roofs and poorly stored chemicals (see Nature 385, 378; 1997).

The Paris research collections are rivalled only by those of the Smithsonian Institution in Washington and the British Museum of Natural History in London. They include 2 million fossils, 150 million insects, and 1.5 million vertebrates.

The Smithsonian Institution has transferred 20 million specimens to a purposebuilt storage and research centre just outside Washington, but collections in Paris are often piled in boxes in corridors. The refurbishment programme should provide storage and research conditions to keep specimens free from insects, dust, and extremes of temperature and humidity.

Philippe Janvier, a vertebrate paleontologist at the museum, welcomes the promise of new money, but will "wait and see" if it appears. He says that several previous plans, including a much needed renovation of the palaeontology gallery, have ended up gathering dust with the specimens.

But Courtillot and Moreno insist that physical renovation must be accompanied by a modernization of the museum's activities.

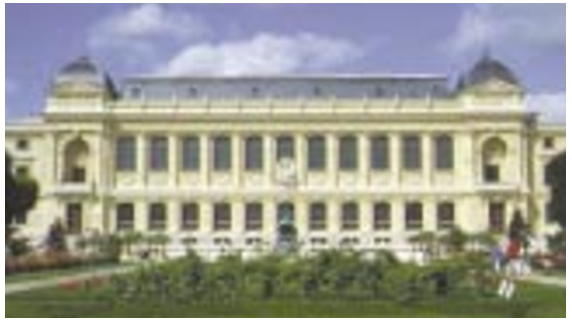

Time for a change: the Natural History Museum in Paris is in urgent need of modernization.

Moreno is no stranger to the museum. He oversaw the FF500 million renovation of its Grand Galerie (see Nature 362, 280; 1993), completed in 1994, and chairs the state committee responsible for national cultural public works, which proposed the renovation plan.

The interim administrator will have broad powers and does not have to answer to the museum's board or scientific council. Trade unions representing museum staff, which are traditionally wary of government intervention, have welcomed the imposition of direct rule, as has De Lumley.

Under a century-old system, the director and the museum's 26 professors have controlled its laboratories, public exhibition halls, zoos and research collections. But a new management structure seems likely to emerge. "Businessmen and not scientists" should run the museum's non-scientific activities, says Courtillot, arguing that past management has been "incompetent".

Courtillot says the aim is to "confirm and accelerate" the core activities. External funding agencies will need to take scientists' curation work into account in evaluation, he says, given the importance of research collections to biodiversity and environmental research (see Nature 394, 115; 1998).

Courtillot adds that "it is an understatement to say that the research at the museum is not high quality". Individual laboratories are likely to be regrouped as institutes addressing key topics.

The reform is likely to come as a relief to researchers. Administration of the museum has been a "veritable catastrophe" says Janvier, complaining of bureaucracy, long delays in processing grants, and antiquated management tools and methods.

Declan Butler

\section{Busquin targets young people}

\section{London}

The European Union (EU) needs to work harder to increase the popularity of science among the young, says the next leader of its research programmes.

Philippe Busquin, president of Belgium's Socialist Party, signalled his priorities for the EU's impending sixth Framework programme when responding to questions from the European Parliament, which is expected to confirm his appointment as EU research commissioner next week.

He will replace science and education commissioner Edith Cresson, who was at the centre of mismanagement allegations that forced the resignation of the commission in March. But Busquin will concentrate fully on the EU research portfolio. Detailed planning for the sixth Framework programme will begin early next year.

Busquin told the MEPs that Europe needs to attract young people into research to bring the proportion of scientists in the population up to US or Japanese levels.

He also said Europe should "exploit the relative advantage it possesses in areas such as aeronautics, but also pay attention to others with a high job-creation potential, such as biotechnology".

Regarding the possible division of future Framework programmes into basic and applied research, he said there should be "no

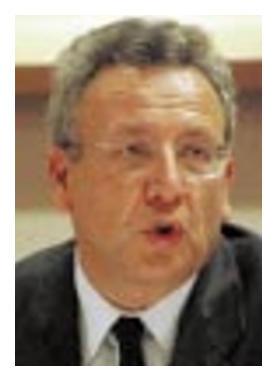

dichotomy" between the two branches of research. Each area of the fifth Framework programme "contains an element of basic research", he said.

Busquin said he would stage a debate on the future of EU

Busquin: incoming EU commissioner. nuclear fusion research following the loss of US support for the

International Thermonuclear Experimental Reactor project.

Busquin's suitability for the job was challenged on both academic and moral grounds. Spanish MEP Alejo Vidal-Quadras Roca said Busquin had no "significant scientific qualifications," but Busquin has a first degree in physics from the Université Libre de Bruxelles, where he was an assistant lecturer for 15 years. He was also chairman of Belgium's Institut de Radioélément and energy minister for the state of Wallonia.

Asked about his involvement in past political scandals and illegal methods used to finance his political party, Busquin said he had never been accused of any illegal transactions or fraudulent behaviour and that the financing problems arose before he was elected president.

(

